DOI: https://doi.org/10.33739/2587-5434-2020-3-104-109

\title{
TEACHING VOCABULARY THROUGH LANGUAGE GAMES - ANAGRAM
}

\author{
Meri Giorgadze \\ PhD in Philology \\ Ivane Javakhishvili \\ Tbilisi State University \\ (Tbilisi, Georgia) \\ e-mail: maiagiorgadze@ymail.com
}

\begin{abstract}
As is well-known vocabulary teaching/learning has always been an essential part of foreign language acquisition. There are various approaches to teaching/learning vocabulary and spelling but there is not any universal way of teaching ones.

This paper deals with the study of anagram as one of the types of wordplay and its usage in vocabulary teaching. The study focuses on the effectiveness of different anagram techniques, activities and "anagrambased games" employed in the process of teaching/learning vocabulary.

In the article, the study was grounded on the experimental method to reveal and summarize the research on the importance of using "anagram-based games" and their educational benefits of vocabulary acquisition.
\end{abstract}

Keywords: Anagram, vocabulary, language games, teaching, learning

\section{ОБУЧЕНИЕ СЛОВАРНОМУ ЗАПАСУ ЧЕРЕЗ ЯЗЫКОВЫЕ ИГРЫ - АНАГРАММА}

\author{
Мери Гиоргадзе \\ Доктор философии \\ Иване Джавахишвили \\ Тбилисский государственный университет \\ (Тбилиси, Грузия) \\ e-mail: maiagiorgadze@ymail.com
}

\begin{abstract}
Аннотация. Как и известный словарь, преподавание/обучение всегда было важной частью изучения иностранного языка. Существуют различные подходы к преподаванию/обучению словарного запаса и орфографии, но универсального способа преподавания нет.

В данной работе рассматривается изучение анаграммы как одного из видов игры слов и ее использование в преподавании словарного запаса. Исследование сосредоточено на эффективности различных техник анаграмм, видов деятельности и "игр на основе анаграмм", используемых в процессе преподавания/обучения словарного запаса.

В статье исследование было основано на экспериментальном методе выявления и обобщения исследований о важности использования "анаграммных игр" и их образовательной пользе от овладения словарным запасом.
\end{abstract}

Ключевые слова: Анаграмма, словарь, языковые игры, преподавание, обучение 


\section{INTRODUCTION}

Nowadays, modern pedagogy should consider wordplay techniques and language games as the pedagogical instrument; teachers should use various activities in the teaching process as a key tool to create "home to home" atmosphere at class. The process of English language learning/teaching should be exciting, enjoyable, effective and meaningful for students to motivate them.

Generally, we can all agree that while acquiring a foreign language, vocabulary represents one of the most important micro-skills to develop. There is no doubt that all micro-skills like grammar, pronunciation, spelling, etc. are vitally important in their ways, but it is far more difficult to communicate and express one's opinion with having no good vocabulary stock rather than knowing grammar. As linguist Wilkins noted (1972) “... without grammar very little can be conveyed, without vocabulary, nothing can be conveyed".

Thus, the importance of vocabulary is fundamental to English language teaching/learning since without having sufficient knowledge of lexis, it is impossible to understand others or express ideas clearly.

In this proposed research paper, I make an attempt to answer the following questions: How do students add words to their mental lexicon? What methods, strategies, and techniques do teachers use to teach vocabulary effectively? How to use language games (anagram-based activities) while teaching/learning vocabulary and spelling? How to make the teaching process mutually enjoyable from the perspectives of teachers and students? These are the main issues discussed in the presented article. Consequently, this paper aims to study different approaches and strategies for teaching/learning vocabulary through one of the types of wordplay - anagram.

\section{REVIEW OF LITERATURE}

According to some scholars, Maximo (2000), Read (2000), Nation (2001) and others, the acquisition of vocabulary is essential for successful second language use and plays a vital role in the formation of complete spoken and written texts.

The empirical study material of the research is taken from my scientific works: Monograph - Wordplay Specifics (Semantic and Pragmatic Parameters) (Giorgadze 2019), Language Games (Anagram, Acrostic, Alliteration) (Giorgadze 2018).

\section{RESEARCH METHODS}

Following the theoretical and methodological bases of study material, we use analytical and experimental methods of research. This implies the description of the facts and results of the observation and experiment conducted at Ivane Javakhishvili Tbilisi State University (TSU).

\section{RESULTS AND DISCUSSION}

Before presenting the results of our experimental research let us say a few words about an anagram and its categories, which I suggested, defined and introduced in my monograph. (Giorgadze, 2019).

An anagram is a type of wordplay created as a result of rearranging the letters of an initial word, phrase, sentence, quote or the like to produce a new word, phrase, etc. in a different order.

In my research work, the above-mentioned literary device is analysed as one of the types of wordplay that is classified into two categories - complete and incomplete types of anagrams.

In case of an incomplete anagram, some letters are lost while rearranging the constituent letters of an initial word or a phrase. e. g. "teacher" - tea, each, ache, are, etc.

Any word or phrase that unerringly reproduces the letters in a different order is an example of a complete anagram. e. g. eat - tea; vacation time - I am not active; Osama bin Laden - A bad man, no lies (Larry Brash) and so on.

Based on the research work, incomplete types of anagrams are widespread.

Intending to obtain reliable results and define the efficiency of the anagram technique in teaching/learning vocabulary, we have conducted an experiment. Two target groups (Group A and Group B) 
were selected and observed. The objects of the experiment were 30 students - 15 students in each group, level - elementary. The main tool used under the investigation of the experiment was a test to measure the students' vocabulary capacity (pre-test before the experiment and post-test after the experiment).

The duration of the experiment was one month, a total of 12 lessons. Before the experiment, both of the target groups wrote a pre-test consisted of 20 multiple choice questions (the test was designed for measuring the spelling and vocabulary knowledge of students). Under the experiment, only with one focus/experimental group (Group A), we used new approaches, strategies, and methods, namely, activities based on anagram games; As for the Group B - classic, standard teaching methods (without using any anagram activities and language games). We observed the students' academic achievement during the experimental time. After the experiment, students in both groups wrote a post-test. It turned out that the students in the experimental group (Group A) performed better results, made fewer spelling mistakes and learned more new words. Furthermore, they were more enthusiastic, motivated and actively involved in the whole work process.

The findings of the presented study have shown that teaching vocabulary through language games (using anagram technique) is beneficial in many different viewpoints. By using the anagram based activities during the teaching/learning process, students' verbal fluency and information processing are trained, that help learners remember spelling and boost their vocabulary memory.

As for the usage of anagram techniques and activities, while teaching/learning vocabulary, there are a variety of games based on the anagram principle. In this section of the research paper, I would like to offer anagram activities some of which were also exploited during the experiment under investigation. (Giorgadze 2018).

\section{Classic Anagram Game}

Language learners (in groups, in pairs or individually) are given an initial word or a phrase and are challenged to use some or all of the constituent letters of the given word or phrase to produce other words or phrases. A variation on this game requires the player(s) to create as many words (phrases) as possible.

At a beginner level students can be given 3-4-5 letter words and at upper levels longer words, it depends on a teacher's choice.

For example: Create as many anagrams as possible out of the word teacher:

TEACHER - Tea, at, eat, ate, her, ache, cheer, cat, cheat, cheater, etc.

\section{Anagram Game with Pictures}

Players (in groups, in pairs or individually) are given special handouts with scrambled words and pictures on them. Pictures are provided as clues for each anagram. Students are supposed to unscramble the letters to get meaningful words for each photo.

For example: Write an animal anagram for each word - a picture is provided as a clue:

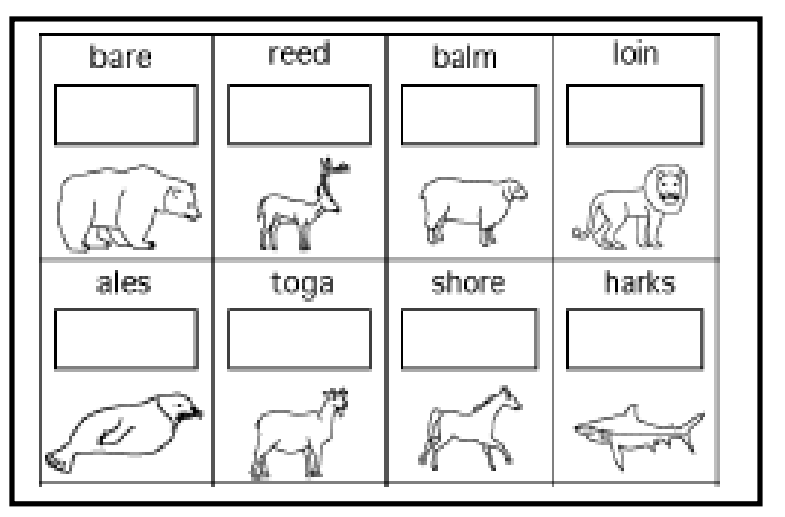




\section{Guessing Anagram Game}

Players (in groups, in pairs or individually) are given special handouts with scrambled words or phrases and definitions. The definition is provided as a clue for each anagram. Students are assumed to unjumble the letters to get a word following the given definitions. All of the letters from the original word(s) must be used exactly once in the new configuration to qualify as an anagram.

It can be done as a warm-up activity or a time-filler to check the students' prior vocabulary knowledge or check the understanding of the new words of the new material.

For Example: Read the definitions and try to guess the anagrams:

CRESOC - Another name for football (Soccer)

HEBCH - Something to sit on in the garden (Bench)

ARBYRIL - Borrow a book from here (Library)

\section{Story Anagram Game}

In this activity, students (in groups, in pairs or individually) are given a handout with a story on it. Some words or phrases in a story are scrambled and underlined. Students are challenged to decode scrambled words or phrases and guess the anagrams that fit the text logically. At a beginner level, students can be given easier stories at upper levels more complex ones.

For example: Read the following story and decode each underlined words or phrases to guess the anagrams that logically fit the text:

$$
* * *
$$

Thinking of you, dear neat chair, would soon come to the red nuts and gin of what I write you in a rag

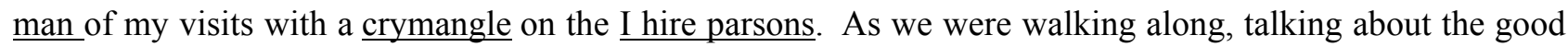
deeds of Flit on cheering angel, we suddenly met a crowd around the moon starer. Asking him if it was a rare mad frolic, he said, "Tis no demon's art," and that he was holding his the bar watching the moon shining up with sapoilo and trying to enlighten the ten tea pots of different countries."

We did not take much stock in their real fun or to love ruin. Two sly ware came up to us and said, "We don't see much the law in this."

We had never sympathized with the doctrines of Sin sat on a tin tar tub. Our first call was on a popular house rats, who had just returned from an horse cart concert. We had a pleasant call, and as we came out we saw a go nurse and Dr. Rich able man driving at full speed. In great no stern action we followed them, and found a just master hurt by the cars. When the excitement was over, we were Tim in a pet to return home, so that ended our visits to the I hire parsons.

\section{ANSWERS:}

Thinking of you, dear Catherine, would soon come to the understanding of what I write you in anagram of my visits with a clergyman on the parishioners. As we were walking along, talking about the good deeds of Florence Nightingale, we suddenly met a crowd around the astronomer. Asking him if it was a radical reform, he said, "Demonstration," and that he was holding his breath watching the moon shining up with oil soap and trying to enlighten the potentates of different countries.

We did not take much stock in their funeral or revolution. Two lawyers came up to us and said, "We don't see much wealth in this."

We had never sympathized with the doctrines of transubstantiation. Our first call was on a popular authoress, who had just returned from an orchestra concert. We had a pleasant call, and as we came out we saw a surgeon and Dr. $\underline{\text { Chamberlain }}$ driving at full speed. In great consternation we followed 
them, and found James Stuart hurt by the cars. When the excitement was over, we were impatient to return home, so that ended our visits to the parishioners.

(https://www.studenthandouts.com/study-games/printable-games/brain-teasers/a-story-inanagrams-worksheet-for-kids.htm)

Anagram Games can be used as warming-up activities, time-fillers, pre or post-class activities to enhance students' vocabulary knowledge.

Creating and designing anagram games and activities are absolutely up to teachers' choices, needs, and their creative minds.

\section{CONCLUSION}

Thus, the research has been based on the effectiveness of anagram activities and their usage in the teaching/learning process. The conducted experiment of the presented study reveals that the use of anagram games in teaching process has many educational benefits. It automatically increases learners' interests in learning more words, enhancing thinking ability and memorizing correct spelling of words. Anagram games improve brain function, verbal fluency and develop team working skills and overall productivity as well. Moreover, it is noteworthy that teaching through language games is fun and mutually enjoyable from teachers and students' perspectives.

\section{LIST OF REFERENCES}

Giorgadze, M. (2018). Book: Language Games - Anagram, Acrostic, Alliteration. Nino Rekhviashvili Publishing House, ISBN 978-9941-8-0494-6; Tbilisi, Georgia.

Giorgadze, M. (2019). Monograph -Wordplay Specifics (Semantic and Pragmatic Parameters); Nino Rekhviashvili Publishing House, ISBN 978-9941-27-430-5; Tbilisi, Georgia.

Maximo, R. (2000). Effects if rote, context, keyword, and context/ keyword method on retention of vocabulary in EFL classroom, Language Learning, 50, 2, 385-412.

Nation, I. S. P. (2001). Learning vocabulary in another language. Cambridge: Cambridge Read, J. (2000). Assessing vocabulary. United Kingdom: Cambridge University Press.

Wilkins, David A. (1972). Linguistics in Language Teaching. Edward Arnold, London.

\section{For citation:}

Giorgadzedze, M. (2020) Teaching Vocabulary Through Language Games - Anagram // International Scientific-Pedagogical Organization of Philologists " WEST-EAST" (ISPOP). Scientific Journal WESTEAST. Vol 3 N1 (October, 2020). p.p. 104-109. https://doi.org/10.33739/2587-5434-2020-3-104-109

\section{Для цитирования:}

Гиоргадзе, М. (2020) Обучение словарному запасу через языковые игры - анаграмма // International Scientific-Pedagogical Organization of Philologists "WEST-EAST" (ISPOP). Scientific Journal "WESTEAST". Vol.3, N1 (October, 2020). C.104-109. https://doi.org/10.33739/2587-5434-2020-3-104-109

\section{Information about the author:}

Meri Giorgadze - Doctor in English Philology (Linguistics), Lecturer at Ivane Javakhishvili Tbilisi State University and Caucasus University.

e-mail: maiagiorgadze@ymail.com megiorgadze@cu.edu.ge meri.giorgadze@tsu.ge 


\section{Сведения об авторе:}

Мери Гиоргадзе - доктор философии по английской филологии (лингвистика), Иване Джавахишвили Тбилисский государственный университет, Тбилиси, Грузия.

e-mail: maiagiorgadze@ymail.com

Manuscript received: 12/08/2020

Accepted for publication: $14 / 09 / 2020$

Рукопись получена: 12/08/2020

Принята к печати: 14/09/2020

\section{International Scientific-Pedagogical Organization of Philologists "West-East" - ISPOP SCIENTIFIC JOURNAL "WEST-EAST" \\ ISSN (print) - 2587-5434 ISSN (online) - 2587-5523}

